\title{
Geology
}

\section{Huge erratic boulders in Tonga deposited by a prehistoric tsunami}

Cliff Frohlich, Matthew J. Hornbach, Frederick W. Taylor, Chuan-Chou Shen, 'Apai Moala, Allan E. Morton and Jens Kruger

Geology 2009;37;131-134

doi: 10.1130/G25277A.1

\section{Email alerting services}

\section{Subscribe}

\section{Permission request}

click www.gsapubs.org/cgi/alerts to receive free e-mail alerts when new articles cite this article

click www.gsapubs.org/subscriptions/ to subscribe to Geology

click http://www.geosociety.org/pubs/copyrt.htm\#gsa to contact GSA

Copyright not claimed on content prepared wholly by U.S. government employees within scope of their employment. Individual scientists are hereby granted permission, without fees or further requests to GSA, to use a single figure, a single table, and/or a brief paragraph of text in subsequent works and to make unlimited copies of items in GSA's journals for noncommercial use in classrooms to further education and science. This file may not be posted to any Web site, but authors may post the abstracts only of their articles on their own or their organization's Web site providing the posting includes a reference to the article's full citation. GSA provides this and other forums for the presentation of diverse opinions and positions by scientists worldwide, regardless of their race, citizenship, gender, religion, or political viewpoint. Opinions presented in this publication do not reflect official positions of the Society.

\section{Notes}

(C) 2009 Geological Society of America

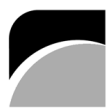

THE GEOLOGICAL SOCIETY OF AMERICA 


\title{
Huge erratic boulders in Tonga deposited by a prehistoric tsunami
}

\author{
Cliff Frohlich1*, Matthew J. Hornbach'1, Frederick W. Taylor', Chuan-Chou Shen², 'Apai Moala', Allan E. Morton ${ }^{4}$, Jens Kruger ${ }^{5}$ \\ IInstitute for Geophysics, John A. and Katherine G. Jackson School of Geosciences, University of Texas at Austin, \\ Austin, Texas 78758-4445, USA \\ 2Department of Geosciences, National Taiwan University, Taipei 10617, Taiwan, Republic of China \\ ${ }^{3}$ Geology Section, Ministry of Lands, Survey, and Natural Resources, Nuku'alofa, Tonga \\ ${ }^{4} 343$ Harvard Avenue, Rexburg, Idaho 83440, USA \\ ${ }^{5}$ SOPAC, South Pacific Islands Applied Geoscience Commission, Nabua, Fiji Islands
}

\begin{abstract}
Along some coastlines there are erratic boulders apparently emplaced by tsunamis or cyclonic storms; evaluating their origin and time of emplacement places constraints on the frequency, severity, and location of coastal hazards. Seven such large coral limestone boulders are present near Fahefa village on Tongatapu Island, southwest Pacific, apparently emplaced by a prehistoric tsunami. These boulders are 10-20 $\mathrm{m}$ above sea level and above any possible source, and all are $100-400 \mathrm{~m}$ from the present shoreline. Coral ${ }^{230} \mathrm{Th}$ ages indicate that the limestone formed during the last interglacial sea-level highstand, ca. 120-130 ka. The largest boulder is 20 times more massive than any reported boulders emplaced by historically documented storms and may be the largest known tsunami or storm erratic worldwide situated above its source. We performed computer simulations to assess whether tsunamis produced by earthquakes, undersea landslides, or volcanoes could emplace the boulders. The simulations indicate that either volcanic flank collapse along the Tofua arc $\sim 30-40 \mathrm{~km}$ to the southwest or undersea landslides on the submarine slopes of Tongatapu could be responsible. Either could explain why these boulders are not widespread on Tongatapu, and instead occur in a localized group along the western coast. This study demonstrates that small $\left(<1 \mathbf{k m}^{3}\right)$ submarine slope failures sometimes generate locally large tsunamis. The Fahefa boulders are in a well-studied and well-populated area, yet were unknown to the scientific community until recently; this suggests that systematic searches elsewhere for erratic boulders and other tsunami deposits might provide new information for assessing the size and extent of prehistoric tsunamis.
\end{abstract}

\section{INTRODUCTION}

In many coastal regions waves produced by tsunamis and cyclonic storms present a severe natural hazard, threatening life and property, especially as much of the world's population lives near the sea. Although earthquakes are generally considered the primary tsunami trigger, a growing, if controversial, line of evidence suggests that submarine slides may generate some of the largest tsunamis on Earth (Ward and Day, 2001; Tappin et al., 2001). Assessing potential tsunami hazard is difficult because tsunamis with wave heights in excess of $10 \mathrm{~m}$ are rare historically (Scheffers and Kelletat, 2003; Bryant, 2008). Along many coastlines erratic boulders or other deposits are the only direct evidence that large waves present a hazard (e.g., Nott and Bryant, 2003; Nott, 2004). For prehistoric tsunami waves, computer modeling of potential sources often provides the best available information about their possible origins.

On the island of Tongatapu, southwest Pacific, there are seven huge erratic coral limestone boulders that are on a 3-km-long arc on the western coastline near the village of Fahefa (Figs. 1-2; GSA Data Repository Table DR $1^{1}$ ). The Fahefa stones are the highest features locally; they could only have come from the shoreline, as there are

\footnotetext{
*E-mail: cliff@ig.utexas.edu.
}

no nearby cliffs or hills. Although a recent survey (Pearce, 2007) reported no historically documented tsunamis in Tonga with waves exceeding $2.5 \mathrm{~m}$, the size and locations of the Fahefa stones imply that such waves struck Tongatapu in prehistoric time. In this report we describe these boulders and use computer models to assess scenarios that could emplace them.

Tongatapu is $\sim 35 \mathrm{~km} \times 20 \mathrm{~km}$ and consists of $\sim 3$-km-thick marine sediment deposits overlain by coral reef limestone. The most recent coral limestone includes rare Holocene deposits at a maximum elevation of $2 \mathrm{~m}$ above currently living corals, and a nearly continuous coastal deposit of last interglacial time, ca. 120-130 ka (Fig. 3), with a maximum elevation on western Tongatapu of $7 \mathrm{~m}$ above currently living corals (Taylor and Bloom, 1977). The island is

'GSA Data Repository item 2009036, Section DR1 (dating of coral samples), Section DR2 (estimating wave heights), Section DR3 (computer modeling), Table DR1 (locations and basic characteristics of erratic boulders on southwestern Tongatapu), Table DR2 (uranium and thorium isotopic compositions and ${ }^{230} \mathrm{Th}$ ages for Tonga coral fossils), Table DR3 (parameters used for modeling slides and volcanic flank collapse), and Figure DR1 (validation of agedetermination method), is available online at www. geosociety.org/pubs/ft2009.htm, or on request from editing@geosociety.org or Documents Secretary, GSA, P.O. Box 9140, Boulder, CO 80301, USA. topographically nearly flat, composed of Quaternary coral reef limestone overlain by thick soils formed on 1.5-5.0-m-thick tephra deposits originating from explosive volcanic eruptions along the Tofua volcanic arc (Dickinson and Burley, 2007), a north-south volcanic line $\sim 30 \mathrm{~km}$ west of Tongatapu.

\section{FIELD OBSERVATIONS}

In November 2007 we visited Tongatapu and located the boulders using descriptions provided by Morton (2003). All seven stones are in fields covered mostly with tall grass; the soils nearby usually do not support forest, and digging near the largest boulder revealed anomalously thin soils $(<0.5 \mathrm{~m})$ compared to soils nearby on Tongatapu. The largest boulder (Fig. 2) has dimensions of $15 \mathrm{~m} \times 11 \mathrm{~m} \times 9 \mathrm{~m}$, and is $130 \mathrm{~m}$ from the present shoreline with its base $9.4 \mathrm{~m}$ above mean high tide level (see Table DR1 for distances and elevations of the other boulders). None of the stones is in place, but all contain well-preserved corals. Living corals grow with a distinctly upright orientation, and inspection indicated that the large majority of corals in each boulder had similar orientations; two of the boulders are overturned; one is upright but clearly tilted. The largest stone is approximately upright but clearly not attached at its base as it sits on hard rock and one can see completely beneath it.

We measured heights and circumferences of all the stones. Their heights ranged from $2.5 \mathrm{~m}$ to $9 \mathrm{~m}$ (Table DR1); the volumes $(\pi a b c / 6)$ of these roughly ellipsoidal shapes ( $a=$ length, $b=$ width, $c=$ height) were $780 \mathrm{~m}^{3}, 350 \mathrm{~m}^{3}, 300 \mathrm{~m}^{3}, 130 \mathrm{~m}^{3}$, $100 \mathrm{~m}^{3}, 45 \mathrm{~m}^{3}$, and $35 \mathrm{~m}^{3}$. For a density of $\sim 2.0 \mathrm{~g} / \mathrm{cm}^{3}$ (Spiske et al., 2008), these volumes correspond to masses of 70-1600 metric tons.

The Fahefa boulders form a distinct, localized group unlike stones we inspected elsewhere in Tonga. To assess this we questioned local inhabitants about the whereabouts of "makalahi" (big stones in Tongan), and visited numerous boulders on the islands of Tongatapu, Ha' apai, and Vava'u. All other boulders we inspected were either in place, much smaller, or more highly weathered than the Fahefa stones, or located on beaches below and adjacent to cliffs. One of us (Moala) is a native Tongan and a trained geologist; neither he nor his colleagues employed by the Tongan Ministry of Lands, Survey, and Natural Resources 


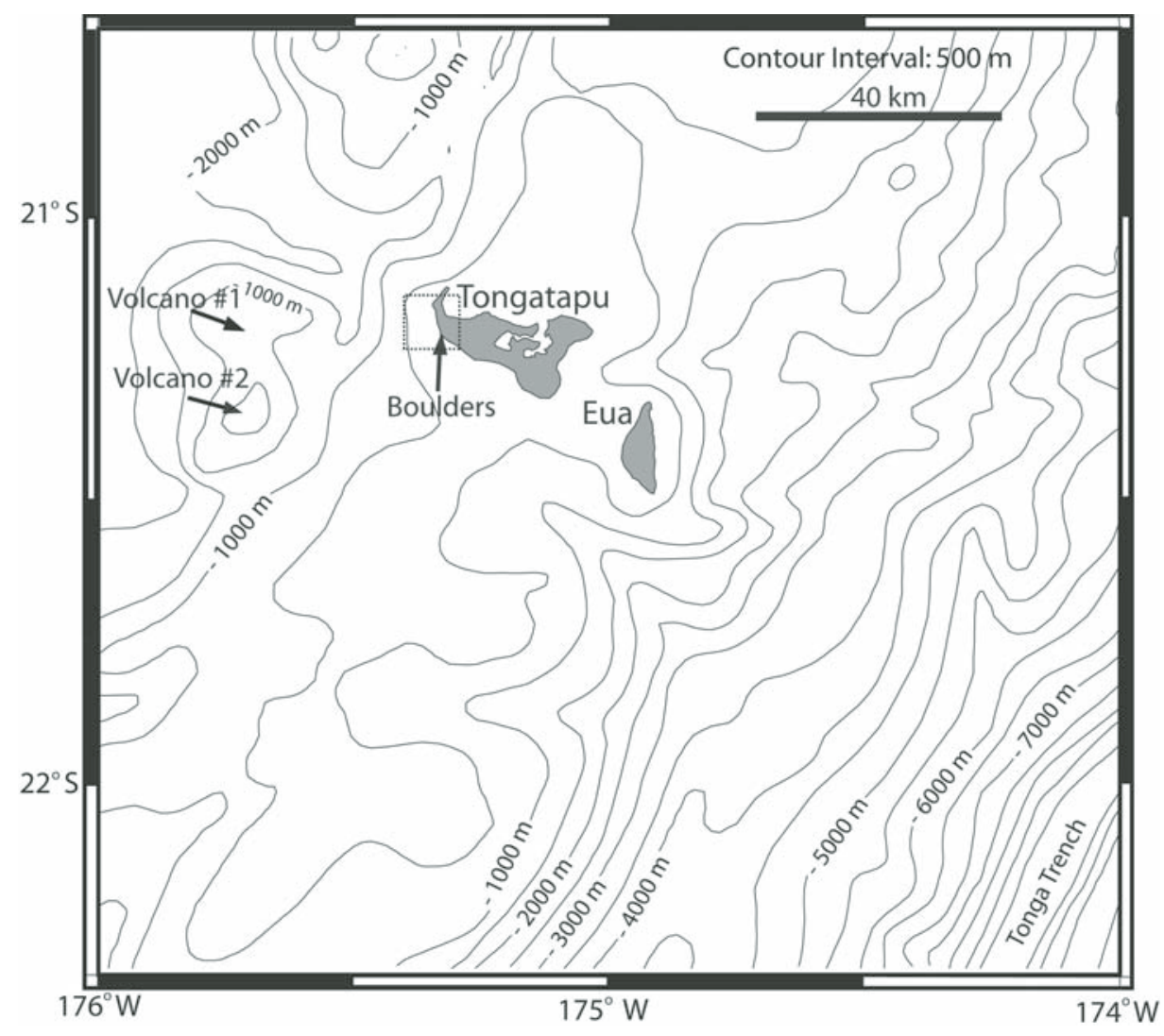

Figure 1. Relationship of Fahefa boulders to possible tsunami sources. Arrows indicate locations of flank collapse features modeled for volcanoes 1 and 2; square indicates location of boulders and modeled undersea slumps shown in Figure 4.

knew of boulders anywhere with all the characteristics of those near Fahefa. Given the relatively uniform geology of Tongatapu, we conclude that the phenomenon depositing the Fahefa stones was localized on western Tongatapu and did not affect other islands.

\section{ANALYSIS AND COMPUTER MODELING \\ Isotopic Dating}

Ages of nine coral samples, collected from six of the Fahefa boulders, were determined with ${ }^{230}$ Th dating methods (Shen et al., 2002) using multicollector-inductively coupled plasmamass spectrometry (Section DR1; Table DR2). U-series results (Table DR2) indicated that seven of the nine samples, representing five different boulders including the largest, were isotopically unaltered. All the reliable ages were between 122 and $131 \mathrm{ka}$, the youngest age being $122.6 \pm 0.5 \mathrm{ka}$. This confirms when the corals lived with an age accuracy of $\sim 1 \%$ and provides a maximum age for the emplacement of the boulders.

\section{Potential Sources}

What brought the Fahefa boulders to their present location? They could not have formed in place, as their bases are all on or above the maximum elevation of sea level in the Holocene or in the last interglacial ca. 120-130 ka (Taylor and Bloom, 1977). The only credible explanation is that a storm wave, storm surge, or large tsunami removed them from the western shore of Tongatapu and transported them 10-20 $\mathrm{m}$ upward and 100-400 $\mathrm{m}$ inland. This was most likely a single event, as the stones share many similarities and now lie along a gentle arc roughly equidistant from the shoreline (Fig. 4). Because they are on a thinner soil layer than in adjacent regions, backwash or a similar scouring process may have accompanied their deposition. boulders. Although cyclonic storms sometimes produce waves or surges that displace boulders (Noormets et al., 2002; Nott, 2004), the largest historically documented stones displaced vertically upward and moved distances exceeding a few meters by storms have average dimensions smaller than $\sim 5 \mathrm{~m}$ and masses $<100 \mathrm{t}$ (Nott, 2004). There has been discussion that sea surface temperatures exceeding $36{ }^{\circ} \mathrm{C}$ might generate hypercanes, i.e., storms much stronger than any observed historically (Parks Camp and Montgomery, 2001). However, no one has yet suggested that such conditions occurred within the past $130 \mathrm{k} . \mathrm{y}$.
It seems unlikely that a storm deposited these

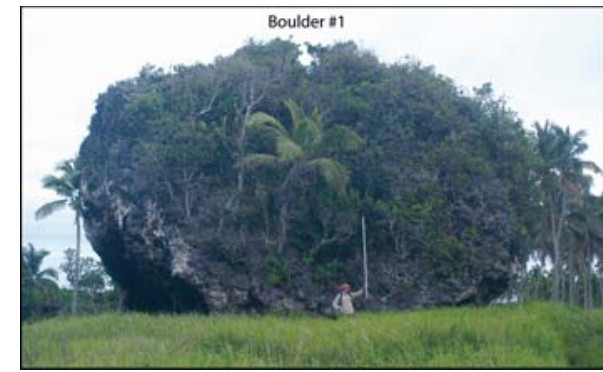

Figure 2. Largest erratic boulder near Fahefa, Tongatapu. This coral limestone boulder (boulder \#1) is roughly ellipsoidal in shape; its base is $10 \mathrm{~m}$ above sea level and $\sim 130 \mathrm{~m}$ from present shoreline; smaller boulder is $80 \mathrm{~m}$ farther inland. Rod in the photo is $2.44 \mathrm{~m}$ long.

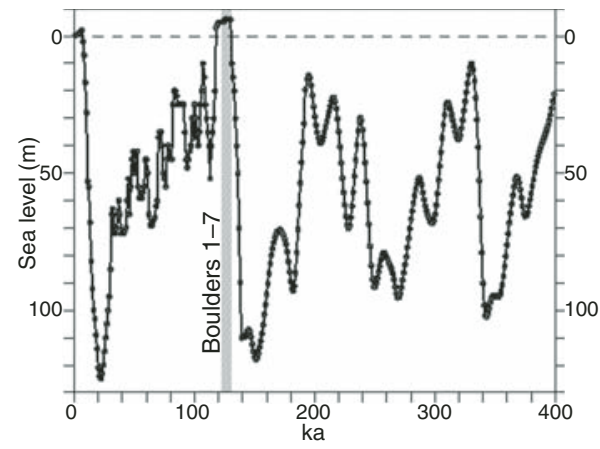

Figure 3. Sea level for Tongatapu over past 400 k.y. Prior to Holocene, sea level had not been at or near present values for $\sim 120$ k.y. Shaded area labeled "boulders 1-7" indicates range of isotopically determined dates for erratic boulders. Plotted sea-level values are determined from analysis of uplifted terraces in New Guinea for period back to 30 ka (Lambeck and Chappell, 2001), and prior to that from proxy relationship between oxygen isotopes, ice volume, and sea level (Imbrie et al., 1989).

Numerous relationships have been proposed to estimate how large a wave is required to move a boulder of height $h$ and density $\rho_{\mathrm{b}}$. Using Nott and Bryant's (2003) equations 13 and 14, we obtain wave height estimates of 19-44 m (Section DR2). Empirical observations suggest that these estimates are low, as the largest limestone boulders displaced by the 27 August 1883 Krakatau $\sim 36 \mathrm{~m}$ tsunami wave and the 24 April 1771 Meiwa $\sim 30 \mathrm{~m}$ tsunami wave had volumes of $317 \mathrm{~m}^{3}$ and $160 \mathrm{~m}^{3}$, respectively (Kato and Kimura, 1983; Setja Atmadja, 2007; Imamura et al., 2008).

Potential tsunami sources include several known submarine volcanoes (Fig. 1) along the Tofua arc $35 \mathrm{~km}$ west of Tongatapu (Massoth et al., 2007); there is a report from 1853 (Sawkins, 1856) of the simultaneous occurrence of a tsunami and earthquake in Tongatapu accompanying the temporary appearance of a new volcanic 

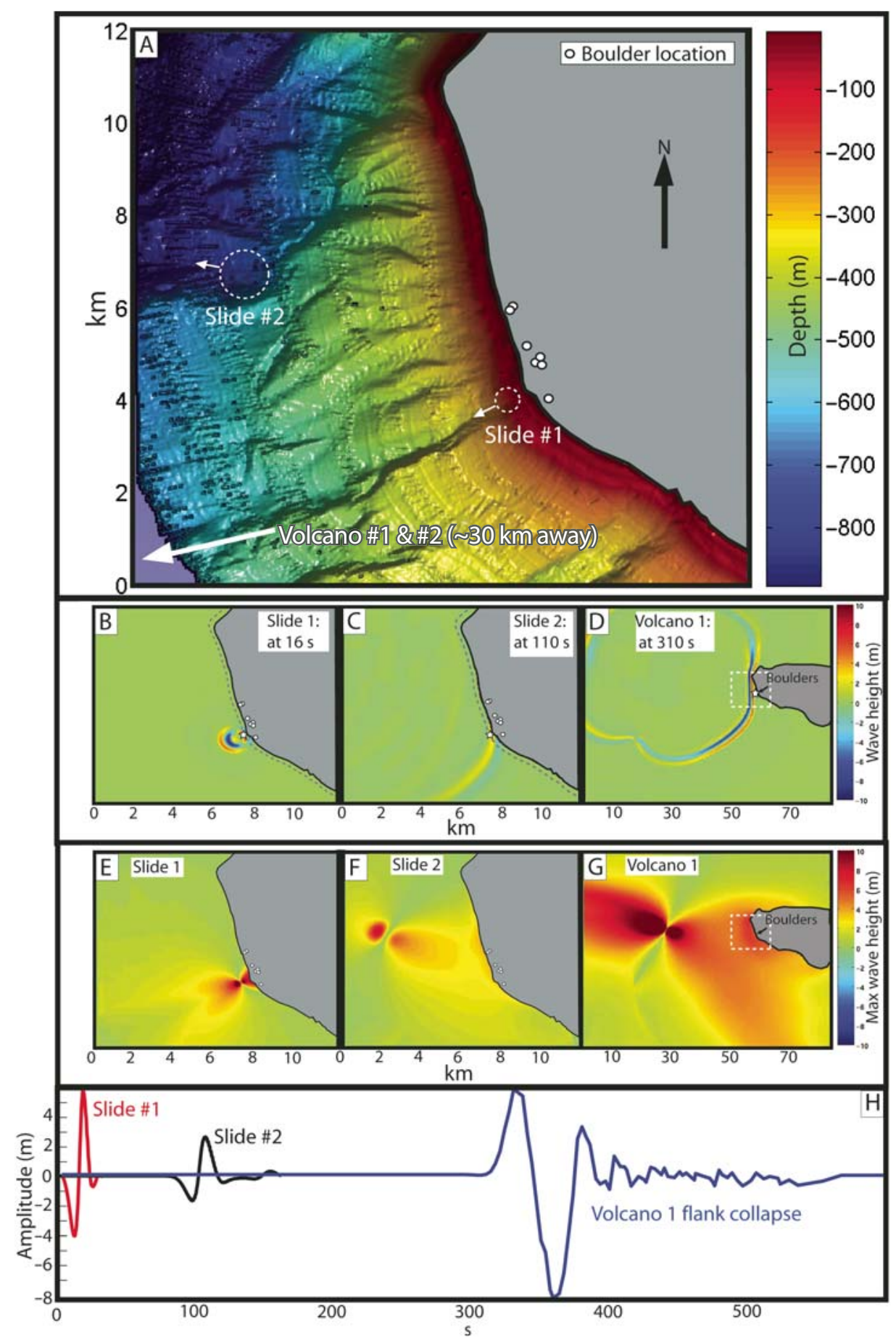

Figure 4. Tsunami modeling results. A: Bathymetry offshore western Tongatapu, locations of Fahefa stones (white circles), and source regions of modeled landslides. B-D: Modeled wave heights at indicated points (labeled with a star; dashed lines show $100 \mathrm{~m}$ water depth) for slide 1 (B), slide 2 (C), and volcano 1 flank collapse (D). E-G: Maximum (Max.) modeled wave heights for slide $1(E)$, slide $2(F)$, and volcano 1 flank collapse (G). H: Time histories of modeled wave heights.

island $45 \mathrm{~km}$ to the west. The Tofua volcanism is potentially explosive because it is silicic, exhibits caldera or collapse features, has deposited thick tephra layers in the soils on Tongatapu (Dickinson and Burley, 2007), and has produced documented submarine explosions that violently resolution bathymetric data (Fig. 1; Table DR3). Slide 1 is a channel-like 50-m-deep depression $\sim 200-500 \mathrm{~m}$ wide that begins $\sim 180 \mathrm{~m}$ from shore, directly seaward of the Fahefa boulders, and extends up to $3 \mathrm{~km}$ offshore, reaching depths of $500 \mathrm{~m}$. Slide 2 is somewhat larger with a width of $\sim 1000 \mathrm{~m}$, and is evident in the bathymetry $\sim 5 \mathrm{~km}$ offshore west-northwest of the Fahefa boulders.

Earthquake ruptures that displace large areas on the ocean floor also may produce tsunamis. Although Tonga is very active seismically, except for one unconfirmed report (Gerber, 2000) concerning a tsunami in Vava'u generated by the 30 April $1919 \mathrm{M}_{\mathrm{w}} 8.2$ earthquake, there is no historical record describing tsunamis exceeding $2.5 \mathrm{~m}$ runup anywhere in Tonga produced by either the largest historically known regional earthquakes (Okal et al., 2004), which have $\mathrm{M}_{\mathrm{w}} 8.4$, or by teleseismic events such as the 1960 Chile $M_{\mathrm{W}} 9.5$ earthquake (Pearce, 2007).

\section{Tsunami Modeling}

We modeled several natural phenomena that might generate tsunamis on Tongatapu, including volcano flank collapses, submarine landslides, and earthquake ruptures that displace the ocean floor (Section DR3). Our computer program simulates wave motion using a standard nonlinear shallow-wave finite-difference approach, i.e., the grid elements have vertical dimensions equal to the water depth and their relative heights determine the wave motion. With the gridded bathymetry available to us we can obtain accurate relative wave heights in water depths of $100 \mathrm{~m}$ or greater, allowing us to identify areas most affected by a tsunami. To simulate waves generated by earthquakes, volcanoes, or submarine landslides, our program uses a gridded pattern of vertical motions. For earthquakes, we use an elastic dislocation model for a rectangular fault in a half space. For volcanoes and submarine slides, our program models a rotational slump as a moving Gaussian function of specified height and width, with the seafloor moving up and down as it passes.

After modeling numerous flank-collapsetriggered tsunamis along the Tofua arc, we conclude that feature volcano 1 at $\sim 21.11^{\circ} \mathrm{S}$, $175.40^{\circ} \mathrm{W}$ is a promising source. Our model finds that a 4-km-diameter, 200-m-thick rotational slump, moving for $10 \mathrm{~s}$ in an eastward direction away from volcano 1 , produces peakto-trough amplitudes of $14 \mathrm{~m}$ at $100 \mathrm{~m}$ water depths off western Tongatapu (Fig. 4).

Two slump features near Tongatapu produced tsunamis with similar wave amplitudes but of shorter durations. Both slumps have their highest amplitudes concentrated along the shoreline seaward of Fahefa. Although the amplitudes offshore seem too small to displace the Fahefa stones (Fig. 4), local bathymetry 
and larger slide volumes might amplify them. For earthquakes, we modeled tsunamis generated by hypothetical moment magnitude $\mathrm{M}_{\mathrm{W}} 9$ earthquakes, which requires slip of $\sim 30 \mathrm{~m}$ along faults with dimensions $\sim 120 \mathrm{~km} \times 1000 \mathrm{~km}$. For sources along the Tonga trench this produces a tsunami that strikes the eastern shores of Tongatapu and other islands in the Tonga arc. Peak-to-trough amplitudes are $\sim 12 \mathrm{~m}$ at Fahefa on the west side of the island.

\section{DISCUSSION}

The computer modeling and other arguments imply that tsunamis generated by volcanic flank collapse events along the Tofua arc or by submarine slumps are the most plausible origins for the Fahefa stones. It is notable that at distances of $30 \mathrm{~km}$ from the Krakatau volcanic eruption of 27 August 1883, a tsunami with reported heights of $36 \mathrm{~m}$ displaced a coral limestone boulder $100 \mathrm{~m}$ inland; its volume of $317 \mathrm{~m}^{3}$ is larger than all but two of the Fahefa stones (Simkin and Fiske, 1983; Setja Atmadja, 2007).

The 122-131 ka dates suggest this event likely occurred either within the past 7 k.y. or ca. 122 ka, rather than at intermediate times when sea level was 15-120 m lower than present (Fig. 3). It could not have occurred before the age of the youngest corals in the blocks $(122.6 \pm 0.5 \mathrm{ka})$. Furthermore, the observation that none of the boulders rests on pedestals, which allegedly form due to rainfall solution beneath objects resting on limestone surfaces (Matsukura et al., 2007) and reportedly grow at rates of $\sim 20 \mathrm{~cm} / \mathrm{k} . \mathrm{y}$., favors a much younger age of $7 \mathrm{ka}$ or younger.

Computer simulations suggest it is unlikely that a local or teleseismic earthquake-induced tsunami emplaced the Fahefa stones. It is implausible that ruptures with dimensions $\sim 1000 \mathrm{~km}$ would leave visible deposits only on western Tongatapu and only within a localized region.

Previous studies suggest that giant to moderate $\left(100-10 \mathrm{~km}^{3}\right)$ submarine slope failures may be responsible for some of the largest tsunamis (Ward and Day, 2001; Tappin et al., 2001). Our study offers geological evidence supporting this hypothesis. Furthermore, our study indicates that perhaps even small $\left(<1 \mathrm{~km}^{3}\right)$ submarine masstransport events, under appropriate geological and geographic conditions, may generate some of the largest near-field tsunamis on Earth.

Additional research concerning waveemplaced deposits in Tonga and elsewhere could provide more quantitative information about potential tsunami and/or storm hazards. We suggest that when assessing wave hazards anywhere worldwide, it may be useful to undertake a systematic search for and census of erratic stones, as they may be more common than we know; before this study, those of us native to Tongatapu (Moala) or who had visited it for geologic field study several times previously (Frohlich and Taylor) were unaware of the Fahefa stones, even though the island is small, well populated, and generally accessible.

\section{ACKNOWLEDGMENTS}

The Jackson School of Geosciences, University of Texas at Austin, supported the field expenses for this project. We thank Elizabeth Dunn for sample preparation, Ke Lin for U-Th chemistry, Gary Massoth and James Goff for useful discussions, and Dave Tappin, Edward Bryant, and two anonymous reviewers for constructive suggestions. This is Institute for Geophysics Contribution 2000.

\section{REFERENCES CITED}

Bryant, E., 2008, Tsunami: The underrated hazard (second edition): Chichester, UK, Springer Praxis, $342 \mathrm{p}$.

Dickinson, W.R., and Burley, D.V., 2007, Geoarcheology of Tonga: Geotectonic and geomorphic controls: Geoarchaeology, v. 22, p. 229-259, doi: 10.1002/gea.20164.

Gerber, T.W., 2000, Iohani Wolfgramm: Man of faith and vision 1911-1997: (city of publication unknown), Tisina Wolfgramm Gerber, $247 \mathrm{p}$.

Imamura, F., Goto, K., and Ohkubo, S., 2008, A numerical model for the transport of a boulder by tsunami: Journal of Geophysical Research, v. 113, C0008, doi: 10.1029/2007JC004170 (2008).

Imbrie, J.D., McIntyre, A., and Mix, A.C., 1989, Oceanic response to orbital forcing in the late Quaternary-Observational and experimental strategies, in Berger, A., et al., eds., Climate and geosciences: A challenge for science and society in the 21st Century: Boston, Kluwer Academic Press, p. 121-164.

Kato, Y., and Kimura, M., 1983, Age and origin of so-called "tsunami-ishi", Ishigaki Island, Okinawa Prefecture: Geological Society of Japan Journal, v. 89, p. 471-474.

Lambeck, K., and Chappell, J., 2001, Sea level change through the last glacial cycle: Science, v. 292, p. 679-685, doi: 10.1126/science.1059549.

Massoth, G., Baker, E., Worthington, T., Lupton, J., de Ronde, C., Arculus, R., Walker, S., Nakamura, K., Ishibashi, J., Stoffers, P., Resing, J., Greene, R., and Lebon, G., 2007, Multiple hydrothermal sources along the south Tonga arc and Valu Fa Ridge: Geochemistry, Geophysics, Geosystems, v. 8, Q11008, doi: 10.1029/2007GC001675.

Matsukura, Y., Maekado, A., Aoki, H., Kogure, T., and Kitano, Y., 2007, Surface lowering rates of uplifted limestone terraces estimated from the height of pedestals on a subtropical island of Japan: Earth Surface Processes and Landforms, v. 32 , p. $1110-1115$, doi: $10.1002 /$ esp. 1510.

Melson, W.G., Jarosewich, E., and Lundquist, C.A., 1970, Volcanic eruption at Metis Shoal, Tonga 1967-1968: Description and petrology: Smithsonian Contributions to the Earth Sciences no. $4,18 \mathrm{p}$.

Morton, A.E., 2003, Evidence for large tsunami in the Tongan Islands: Geological Society of America Abstracts with Programs, v. 35, no. 4, p. 4.

Noormets, R., Felton, E.A., and Crook, K.A.W., 2002, Sedimentology of rocky shorelines: 2. Shoreline megaclasts on the north shore of Oahu, Hawaii-Origins and history: Sedimentary Geology, v. 150 , p. 31-45, doi: 10.1016/ S0037-0738(01)00266-4.

Nott, J., 2004, The tsunami hypothesis-Comparisons of the field evidence against the effects, on the western Australian coast, of some of the most powerful storms on Earth: Marine Geology, v. 208, p. 1-12, doi: 10.1016/ j.margeo.2004.04.023.

Nott, J., and Bryant, E., 2003, Extreme marine inundations (tsunamis?) of coastal western Australia: Journal of Geology, v. 111, p. 691-706, doi: 10.1086/378485.

Okal, E.A., Borrero, J., and Synolakis, C.E., 2004, The earthquake and tsunami of 1865 November 17: Evidence for far-field tsunami hazard from Tonga: Geophysical Journal International, v. 157, p. 164-174, doi: 10.1111/j.1365-246X. 2004.02177.x

Parks Camp, J., and Montgomery, M.T., 2001, Hurricane maximum intensity: Past and present: Monthly Weather Review, v. 129, p. 1704 1717.

Pearce, H., 2007, Inventory of geospatial data available and options for tsunami inundations, and risk modeling, Tonga: SOPAC/GA Tsunami Hazard and Risk Assessment Project Report 01: Suva, Fiji, SOPAC Secretariat, 55 p.

Sawkins, J.G., 1856, On the movement of land in the South Sea islands: Geological Society of London Quarterly Journal, v. 12, p. 383-384, doi: 10.1144.GSL.JGS.1856.012.01-02.51.

Scheffers, A., and Kelletat, K., 2003, Sedimentologic and geomorphologic tsunami imprints worldwide-A review: Earth-Science Reviews, v. 63 , p. 83-92, doi: 10.1016/S0012-8252 (03)00018-7.

Setja Atmadja, C.M., 2007, Onshore boulder deposits near Krakatau volcano, Indonesia: Eos (Transactions, American Geophysical Union), v. 88, no. 23.

Shen, C.-C., Edwards, R.L., Cheng, H., Dorale, J.A., Thomas, R.B., Moran, S.B., Weinstein, S.E., and Edmonds, H.N., 2002, Uranium and thorium isotopic and concentration measurements by magnetic sector inductively coupled plasma mass spectrometry: Chemical Geology, v. 185 , p. $165-178$, doi: 10.1016/S00092541(01)00404-1.

Simkin, T., and Fiske, R.S., 1983, Krakatau 1883: The volcanic eruption and its effects: Washington, D.C., Smithsonian Institution Press, $464 \mathrm{p}$.

Spiske, M., Böröcz, Z., and Bahlburg, H., 2008, The role of porosity in discriminating between hurricane and tsunami emplacement of boulders-A case study from the Lesser Antilles, southern Caribbean: Earth and Planetary Science Letters, v. 268, p. 384-396, doi: 10.1016/ j.epsl.2008.01.030.

Tappin, D.R., Watts, P., McMurtry, G.M., Lafoy, Y., and Matsumoto, T., 2001, The Sissano Papua New Guinea tsunami of July 1998-Offshore evidence on the source mechanism: Marine Geology, v. 175, p. 1-23, doi: 10.1016/S00253227(01)00131-1.

Taylor, F.W., and Bloom, A.L., 1977, Coral reefs on tectonic blocks, Tonga island arc: Proceedings of the Third International Coral Reef Symposium, Miami, v. 2, p. 275-281.

Ward, S.N., and Day, S., 2001, Cumbre Vieja volcano-Potential collapse and tsunami at La Palma, Canary Islands: Geophysical Research Letters, v. 28, p. 3397-3400, doi: 10.1029/2001GL013110.

Manuscript received 20 June 2008

Revised manuscript received 25 September 2008

Manuscript accepted 6 October 2008

Printed in USA 